$\overline{\text { 論 } \quad \text { 文 }}$

\title{
カタホレシス管の構造と応用
}

\author{
正会員 岩 田倫 典 ${ }^{*}$ 正会員 宮田豊 夫**

\section{Study of the Structure and its Application of the Cataphoresis lamp.} \\ by Tomonori Iwata (Member) and Toyoo Miyata (Member) \\ (Dept. of Electric Engineering Defense Academy)
}

\begin{abstract}
Though the cataphoresis phenomena was found in 1934, yet its application has not heen studied.

The original cataphoresis lamp was proposed by Druyvesteyn, and we studied more advantaged structure of the cataphoresis lamp as a temperature indicator, and the length of poly color in the tube can be varied with the tube current and ambient temperature respectively.

The properties of seperated color and the sharpness of color transition are also studied in this paper from the view point of the nature of atoms in the tube. Poissoner current is also decided by the relation between the atom nature of rare gas and metal vapour.

\section{論 文 要 旨}

カタホンシス現象の発見は古、1934年にさかのぼるが，その応用は全くといって良い程加りみられていな かった。

この現象の発見にともなってカタホレシス放電灯が，M. J. Druyvesteyn 氏によって提案された，筆者はこの 放電管方，温度表示灯としての応用面有し，さらに多色発光放電灯としての実用洒值のあること提案し，こ の放電灯の発光色が多色であり, 加この発光带の伸び，管壁温度打よび管電流によって谷易に伸縮し，これが 電流抢よび管壁温度の関数であることを羿めた。

この発光带の境界は封入される希ガスの性質によって異なり，さらにPoissoner Currentによる境界の性質抢 よび磁界によるカタホレシスの各発光帯の不連続集束も論述する.
\end{abstract}

\section{1.はしがき}

カタホレシス現象は古くF. M. Penning 氏11によって 発見され, M.J. Druyvesteyn 氏2》よっって解析され 1，2のカタホレシス管がこの応用として提唱された。

しかしこの放電管はあまり奏用性がないとして放置さ れていた，R. Rietz 氏と G.H. Diek ${ }^{3)}$ 氏は逆にこの現 象をガスの浄化の一手段として利同しようと提案してい る.

筆者はこの現象を積極的に利用し, 新しいカタホレシ ス管を提案し，その実用化を報じて来ている4).

カタホレシス管の特徽は 2 種以上のガス在同一放電管 内に封入し，何ら外部より手を加壳ることなく同一管内 に2 色以上の発光を生せしめ, かつとの発光の領域が電

*防街大学校電気教室 (現日立製作所武蔵工場)

**防衛大学校電気教室
流括よび外囲温度により容易に変動する点である。

筆者の実験に扔いては $\mathrm{Hg}-\mathrm{A}, \mathrm{Hg}-\mathrm{Ne}$ の放電管を用 いたが，この場合に沏いて，希ガスは媒体ガスとして管 内に封入されるが，同時に封入される金属蒸気原子の, 蒸気源の位置が最も大きな問題となり，この構造を各種 作成し，その機構上の考察を試み，さらにこの特黑なる ガスの管内に扔ける配置に対して, 磁界㕜加え不連続集 丛という現象㲎見し，乙れが漂遊陰極としての応用 性, または単なる光束の管内場所に拁ける移行の面加ら みても、はなはな゙脚味のある現象であること走報告す る.

カタホレシス現象を利用し多色発光灯趡作成すること は，この芯用として最も興味があり，この重要なる点は 各発光部分の境界の幅の決定である. この幅は封入ガス の物理的性質により大きく左右され，乙れをスペクトル の強度分布の測定より各種吟味を行った。 


\section{2. カタホレシス管の構造}

カタホレシス現象とは 2 種以上のガスを同一放電管内 亿封入し值流点灯したとき，イオン化電压の小なるもの より陰極江集まり管軸にそって多色の発光をする現象で ある.

この現象を応用した放管であるから，媒体ガスの種 類扔よび金属蒸父の源の位置之構造が問題になる。

筆者等の実験に扔いては $\mathrm{Hg}-\mathrm{Ne}$. 扔よび $\mathrm{Hg}-\mathrm{A}$ を用 いたものであるから $\mathrm{Hg}$ の蒸気源の位置が問題になる。

为 1 図は $\mathrm{Hg}$ 蒸気源としての水銀プールの構造を示し たもので，(a)(b)(c)(d)の4一の形にそれぞれ分類される.

(a)図は水銀プー ルが単に值線的に 放電管主部とつな がり, 陰極前面に 捻いて図のような 関係を有する。乙 れは水銀が管主部 に入り易く，主部 と分波の端部の中 間に水銀蒸気が付
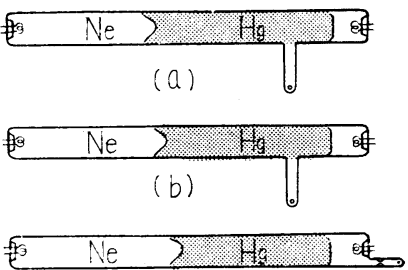

(c)

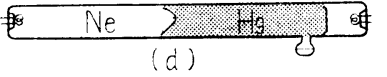

为 1 図カタホレシス琯の構造
着し，放電管の主部の水銀蒸気压を制御し得ない欠点が ある. またこのため主部の水銀蒸気压が外团温腅で制御 しうる範因がはなはな゙せまい。

(b)図は放電管主部之水銀プールの継ぎ目に緗いネック 在作り，(a)図の放電管に把いて琶められるような水銀蒸 父を，水銀蒸父の発生源の壁に付着しないようにしたも のである.これは水銀蒸父を外囲温度で制御するのに。 きわめて有効で実験操作を容易付する．またてれは水銀 粒が管主部に転入するのを防ぐ面で有効である.

(c)図は陰極端部に批いて水銀蒸気源としてのプールの 分岐を，管と直線になるよう設けたものであるが，これ は電界によるポンプ作用が大きく働くために, 温度範囲

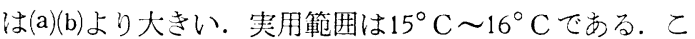
れはプール分伎が管主部にない点が長所である.

(d)図は M. J. Druyvesteyn 氏によって初めて提案さ れたカタホレシス管であるが，水銀粒がすぐ管主部に転 入するため(a)図のカタホレシス管より不利である。

\section{3. 動 作特 性}

カタホレシフ管とは一本の放電管に，2色の発谈領域 を有するものであり， $\mathrm{Hg}-\mathrm{Ne}$ 抢よび $\mathrm{Hg}-\mathrm{A}$ のカタホレ シス放電に批いては，Hg 蒸気による発光带の伸びがこ の働作を決定する最屯興味のある問題となる。乙の動作 特性を明らかにするには，次の各項を検討することが必 要となる。(1)管照温度によって水銀発生带長はごの様に
変化するか，(2)管電流によっって水銀発光帯長はごの様に 変化するか，(3) 2 色発光したとき発光帯の境はどのよう な要素で決定されるか，(4) Hg 発光帯で $\mathrm{Hg}$ 原子はどの 様な分布をしているかである。

\section{1 発光時の外観}

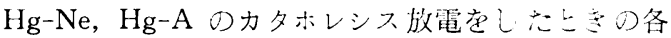
発光状況は，为 2 図に示されるごときものである。

2 図であきらかな

と扰り $\mathrm{Hg}-\mathrm{Ne} の$ ときの境界は明確 であり,すり鈄状 をなしているが $\mathrm{Hg}-\mathrm{A}$ のきの境 界は不明確である このとき $\mathrm{Hg}$ 発 光帯の長さは, 電
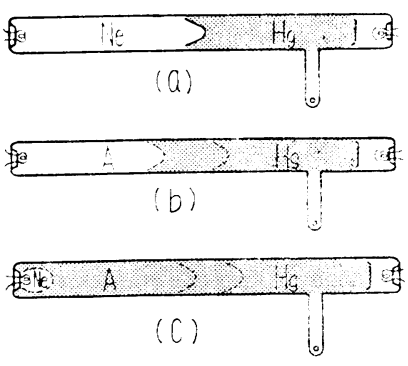

为2図カタホレシス発光状態 流によって容易に変化すると共に管壁温度て制御され る。

为 3 図は $\mathrm{Hg}-\mathrm{Ne}$ カタホレシス管を用いたよミの電流 温度による $\mathrm{Hg}$ 発光帯の伸ごの関係である。

カタホレ
シス現象を
理論的に取
り扱うと
き, $\mathrm{Hg}$ 発
光带と $\mathrm{Ne}$
発光帯の境
界が明白で
あるような
場合, すな
わち希ガス
と金属原子
のイオン化
が，扔の打

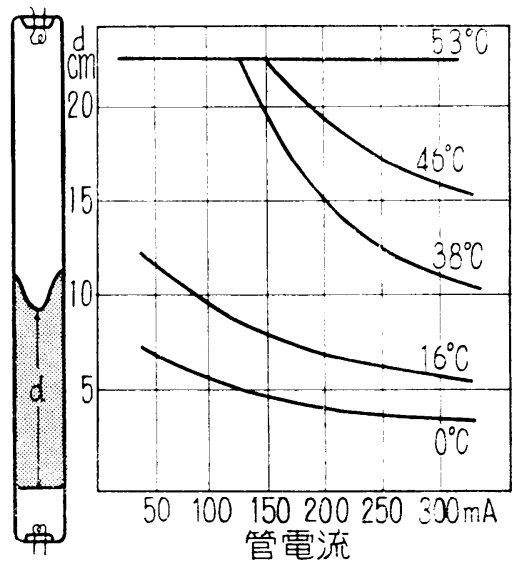

为 3 図 Ne-He 故電管の温度軍流特性
の独立に行なうれるときは，M. J. Druyvestyen 氏によ る運動量平衡の関係丸゙成立する。

$$
-D \frac{d N_{a}}{d x} \pi R^{2}=1.36 n_{+} \mu E_{+} R^{2}
$$

ただし $D$ : 昖散定数 $N_{a}$ : 金属蒸父滵度

$$
\begin{aligned}
& x: \text { 陰極加らの距離 } E: \text { 電位の傾甞 } \\
& R: \text { 管径 } n: \text { プラズマ内のイオン密度 }
\end{aligned}
$$

（1）式が成立する条件は，金属蒸気による発光帯の電 位の傾きが一定であり，また，イオンの移動度も一定で

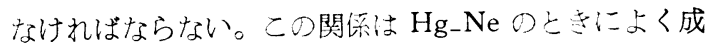
立つ.

(1) 式を積分すれば(2) 式が得られる。

$$
N_{a}(x)=N_{0}-\frac{1.36 \mu_{+} n E}{\pi D} \cdot x
$$


ただし， $N_{0}$ 陰極前面のイオン密度.

金属蒸気による発光帯の伸びをd とすれば，（2 )式に 扣いて $N_{a}(x)=0$ のときの $x$ が $d$ となる.（2）式に拈 ける $x$ の䋆数で $\mu_{+} n_{+} E$ は電流密度を表わし, かつ発光 带の長さ $d$ は一定温度時に招いて $N_{0}$ は一定であるゆ光 (3)式の関係が成立する.

$$
d \propto-\frac{1}{i}
$$

第3罒はこの関係の妥当なることを示している。为3 図の放電管は $8 \mathrm{~mm} \mathrm{Hg}$ の $\mathrm{Ne}$ 管を用いたもので，管径 は $30 \mathrm{~mm}$ で電極間隔は $27 \mathrm{~cm}$ のものである.

$\mathrm{Hg}$ 発光带長dにわたって存在する $\mathrm{Hg}$ 原子の数注, (2) 式党 $\mathrm{Hg}$ 発光带言 $x=0 \sim d$ まで積分すれば与えら れる.

$$
2 \pi R^{2} \int_{0}^{d} N_{a} \cdot d x=\frac{1.36 \mu_{+} u_{+} E}{2 \pi D} d^{2}
$$

この全原子数は管壁温度 $T_{g}$ で定められたものと等し い使用中の温度範囲に招いては, $\mathrm{Hg}$ 原子数は指数関数 であたえられるから（5)式が導かれる。

$$
N_{a}\left(T_{0}\right)=A \exp \left(b T_{0}\right)
$$

(4)式と（5)式を等しいと招くことにより，(6) 式 ガ与えられる.

$$
d=\sqrt{A} \exp \left(b T_{g} / 2\right)
$$

第 3 図の電流をパラメータとして書けば为 4 図が与え られる。これは(6)式の妥当性を更に明ら加にする。

Hg-Aのときは(1) 式の関係が成立しない党, この 関係は成立しなくなる.

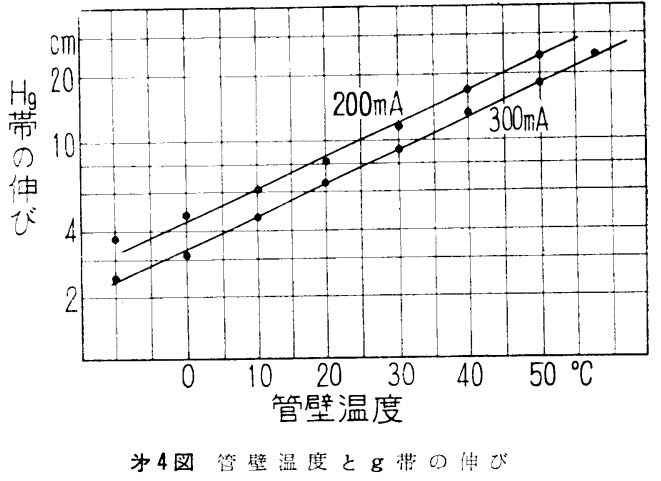

\section{2 発光スペクトルによる吟味}

前節に扣いては $\mathrm{Hg}$ 発光带の分布を, すべて外見上て 吟味し，これが実験とよく一致することをのべたが，こ の発光带の $\mathrm{Hg}$ 原子の分布をさらに $\mathrm{CuCl}_{2}$ 溶液フィル タ打よび UG-1 フィルタと RCA 1 P 2 B の光增幅管を 用いることにより, $\mathrm{Hg}$ スペクトルの内 $3654.8 \AA$, 3650. $1 \AA$ 在探り出し, そのスペクトル強度在测定した。为 5 図はその测定装䔘を示す.

$\mathrm{Hg}-\mathrm{Ne}$ のときの $\mathrm{Hg}$ 原子の分布学示したものが为 6 図（a）であり,この図より明らかなごとく $\mathrm{Hg}$ 発光带は
直線分布をするととがわかる，直線領域よりはずれた領 域は，いわゆる Poissoner 流であり，これは管壁附近の 粘性流である. $\mathrm{Hg}$ 原子の分布の勾配と電流の関係を求 めたのが为 6 図（b）である.

これは(2)式に招ける $\mu_{+} n_{+} E / D$ の一定の関係が正し いことを証明している.

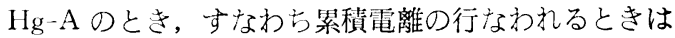
M. J. Druyvesteyn 氏による関係より一層複雑なものに なる. H. Morgenorth3) 氏はこのときの Hg 原子の分

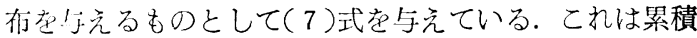
電離の機構を考慮したもので, $\mathrm{Hg}-\mathrm{Ne}$ の境界の分布式 と似たものになる。

$$
N_{a}(x)=N_{0} \exp \left\{-\frac{\alpha i}{\mu_{+}} \int_{0}^{x} \frac{S_{\mathrm{no}_{-}}}{\frac{k T_{e}}{e}} \cdot d x\right\}
$$

ただし $\alpha=1 / D \cdot e \cdot \pi \mu_{+} \quad i:$ 管電流密度

$S_{000}$ : 累積電離を考慮せる衝突断積で $x$ の関数 これは $\mathrm{A}$ を $8 \mathrm{~mm} \mathrm{Hg}$ で $\mathrm{Hg}-\mathrm{Ne}$ の放電管と同一の をの老用いたもの てスペクトル测定 による結果の为 7 図 とよく一致する.

\section{3 カタホッス}

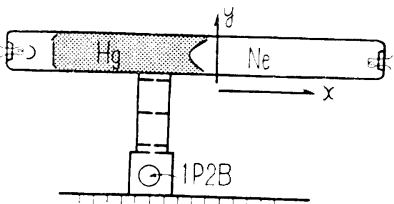

発光の境界

为5図スペクトル測定回路

カタホレ シス発光の 境界を最初 に取り扱っ たのは, M.

J. Druyvesteyn 氏i より与えら れ, この理

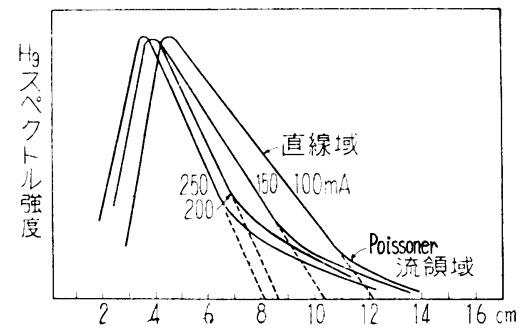
論によれば運動量平 衝の関係加ら(8)式 が与えられる。

$$
\begin{aligned}
& -D \frac{d N_{b}}{d x} \cdot \pi R^{2} \\
& =\beta \cdot S \cdot 1.36 R^{2} \\
& \left(N_{a}+\frac{d N_{a}}{d x} \cdot S\right)
\end{aligned}
$$

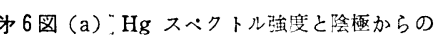
距離

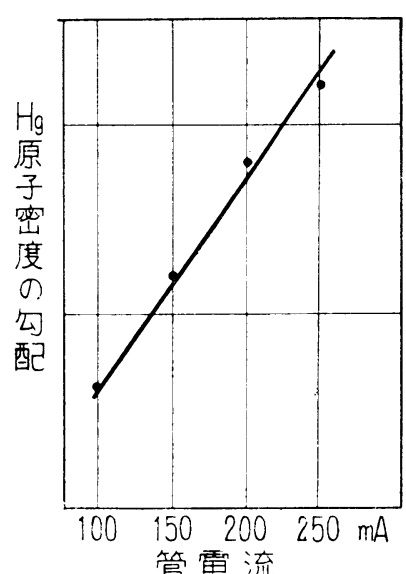

1. $36 R^{2} \mu_{+} n_{+} E$

$=i_{\omega} / e \cdot S$ $=5.21 \mu_{+} u_{+} V_{0} S$
为6 図 (b) 管電流と $\mathrm{Hg}$ 原子密 度の勾配 
（8）式の解は

$N_{a}(x)=N_{0} \exp \left(-\frac{2.1 \times 10^{10} i \cdot \beta \cdot / \lambda-\sqrt{k T_{e} / e \cdot x}}{D+0.28 \times 10^{10} i \beta E / \lambda W\left(\frac{k T_{e}}{e}\right)^{\frac{1}{2}}}\right)$ (9)

但し $\beta N_{a}=n_{+}$であり $\lambda_{-}$は電子の平均自由行程 この式に拓いて $\beta$ は $x$ の関数であるが, 若し $\beta$ を一定 とすれば $\mathrm{Hg}-\mathrm{Nel}$ 対しては $D \ll 0.28 \times 10^{10} i \beta / \lambda-\left(\frac{k T_{e}}{e}\right) \frac{3}{2}$ であり $x$ の係数に単純なものとなる.

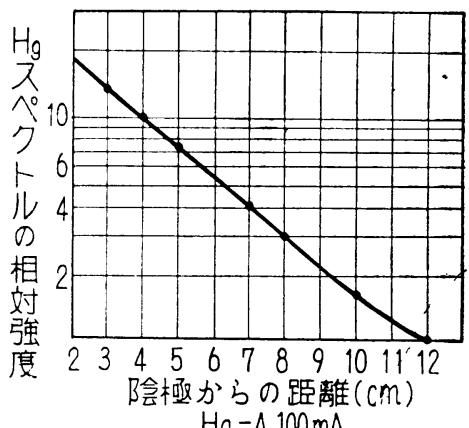
$\mathrm{Hg}-\mathrm{A} 100 \mathrm{~mA}$

为7図 $\mathrm{Hg}-\mathrm{A}$ のときの $\mathrm{Hg}$ スベクトル 强度と陰極加らの距離の関保
カタホレシ

ス放電に打い 管壁電流によ 万分布の㥞相 を为 6 図(a) に示したが Poissoner 領 域をさらに明 確に知るため に筆者らは管 径方向 $y$ 軸に 対して第 5 図 に示す測定装置を用いて $x$ 軸をパラメータとして $\mathrm{y}$ 軸に 刘して測定した。

为 8 図 (a) は $\mathrm{Hg}-\mathrm{A}$ のときである, 为 8 図 (b)は $\mathrm{Hg}-\mathrm{Ne}$ のもので, 実線は直接测定したものもので, 点 線は管中央の断面に打けるスペクトルの相効強度であ る.これより管塹流の管央のイオン流の值を知ることぶ できる.またこれより

$\mathrm{Hg}-\mathrm{Ne}$ のごとくイオ ン化電圧の差の大きい ものほど管壁流がが大

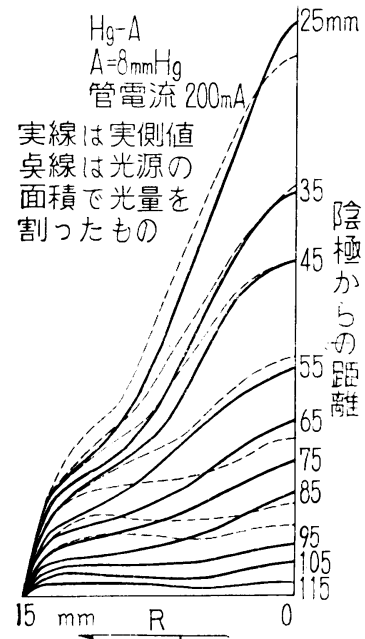

为 8 図 (a) y 軸力向の $\mathrm{Hg}$ スベク トル分布

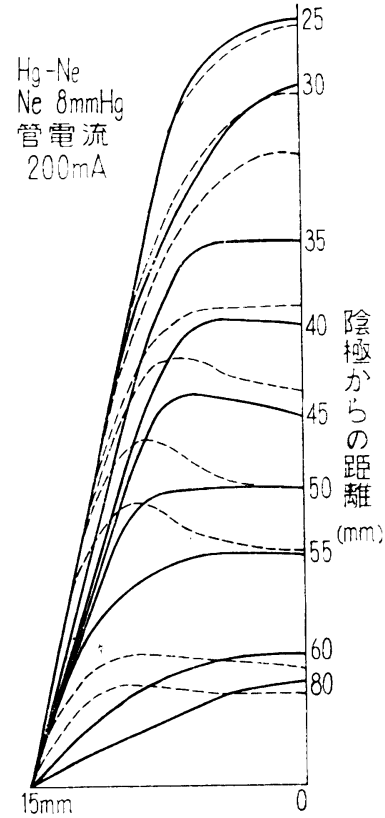

为 8 图 (b) y 軸方向の $\mathrm{Hg}$ スベク トル分布（点線は光源 の量でスベクトル強度 を割つた相対值

きく，イオン化電压の差の小さいものほど管壁流が小き いことがわかる. Na-Ne のとさはほとんど管壁流にな りカタホレシス現象が管径方向に生ずる。为 1 表のカタ ホレシス管として使用されうる原子の電離電圧と原子の 関係よりみても明らかである。

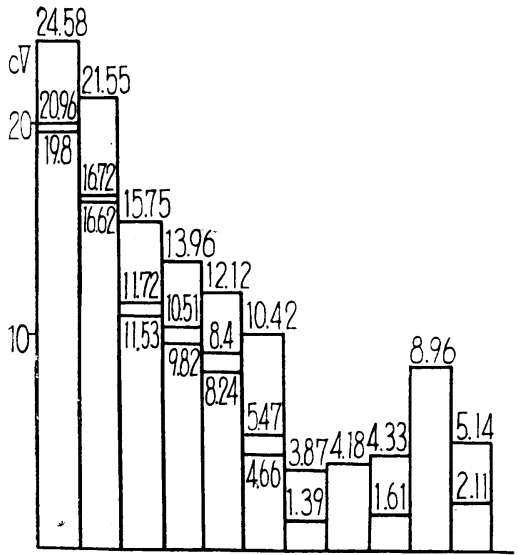

He Ne A Kr Xe Hg Cs Ro K Ca Na

为 1 表 雪離電生, 潐安定電压

この点よ りみて次の ように推論 される。す なわち多色 発光放電灯 はとれら のガスを任 意に組みあ わせれば可 能であるが 各原子のイ オン化電 压, 衙突断 面積にある程度限界があることがわかる。この作成され た放電灯は高温度㳖示灯としても使用可能であり, この 発光色は温度拓よび電流によって制御される。

\section{4. 磁界による不連続集束}

カタホレシス放䉓が電子温度, 空間電荷密度分在, 電 位の傾きよりみて，半学体の P-N 接合に似ていること を指摘したが7)，磁界によるカタホレシス放電陽光柱の 集束の状況ははなはだ䁌味のある様相を呈する。

一般に放電陽光柱の磁界による集束は, 磁界に逆比例 するが，カタホレシス陽光柱のようにイオンの質量の全 く異るものが存在するとき，この磁界による集束がこの 位置により完全に異ることが了解されよう。

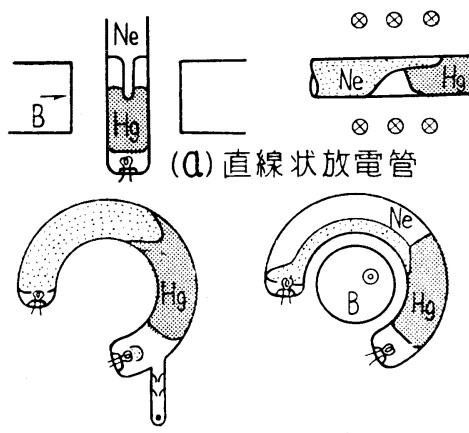

（b）環状力夕札沲管

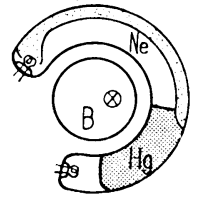

为9図磁界による陽光柱の不連続集束
筆者は，こ の放電陽光柱 に磁界を加光 る際，直線状 放電管打よで 门環状放電管 の両者に関し ての夹験を試 みた。为 9 図 (a) 酒線型 放電管に磁界 を加えた際の 集束状沉二 苏可（b) 依 円環状放電管 
カタホレシス管の構造と応用

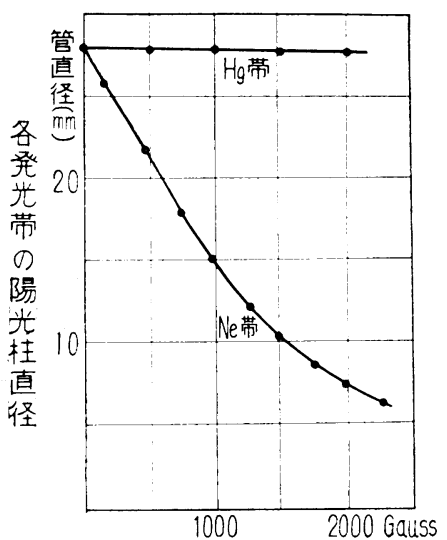

磁石中央の磁界

に磁界を加えた ときの外観であ る. 円環放電管 のときは放電管 内部に加光られ 磁界の強さは, 磁不中央磁界の 約 1/4である が，この際に打 ける陽光柱の集 束の状況は为10 図に示されるよ うなものであ る. この機構と
为10図各発光带と磁界の関第 しては Hg イオン招よび, $\mathrm{Ne}$ イオンの抎散係数抢よび 移動度の差によるものと考えられるが, 細い希ガスの集 束陽光柱と太心 $\mathrm{Hg}$ 蒸気の陽光柱が, 不連続的に集束す る点に興味あり，筆者はこれを不連続集束となづけた。

\section{5. むすひ}

筆者はカタホレシス放電現象を取り扱って, 以下のご とき応用性のある点を指摘し, かつ, この放電現象自体 が陽光柱の内部に空間電荷層を発生させる点で, 各種の 與味を抱いた。

（1）カタホレシス放電管は温度表示灯として使用さ れ，この灾用性は大きい。
正会員 岩田倫典・宮田豊夫

（2）混合ガスを種々用い，カタホレシス管を作成す れば高温の温度表示灯の製作が可能になる.

（3）環状カタホレシス管の磁界による, 不連続集束 の現象は鮮やかであり, 希ガス発光带と水銀発光带の 磁界による，集束の割り合いが䔎だしく異なるため に，希ガスの発光帯の集束プラズマのイオン源，また は漂遊陰極门作成を可能にする。

（4）混㑒ガスの電離電压, 電離能率の差はカタホレ シス発光の, 各発光帯の発光境界の幅を替定する要素 となる.乙の際各種の封入ガスの種類により発光境界 の様相は異なり，かつ，乙れは多色発光放電灯を作成 する上に重大なる示唆を与える.

な拓当研究を行なうにあたり種々御指導頂いた，名大 山本教授扎よび山本研究室各位, ならびに防大安宅教授 に謝意を表わします。（受付. 35-8-10. 再35-11-17）

\section{考文 献}

(1) F.M. Penning: Physica 1. 763 (1934)

(2) M. J. Druyvesteyen : Physica 2. 255 (1935)

(3) R. Rietz \& G. H. Diek: J. appl. Phys. 25. 196 (1954)

(4) 岩田: 電子工業, 8, 63, 昭34

（5）岩田：連大子稿, 88 , 昭35 岩田：物理学会年会, 2 P H 1, 昭35

(6) 岩田: 電学誌, 80,858 , 唈35

（7）岩田：笔子工淛，83，66，昭35

(8) H. Morgenorth; Ann, der phys, 3. 7.373(1959

\section{新製品紹 介}

\section{超高出カビームけい光ランプ}

1. 名称超高出力ビームけい光ランプ

2. 原理特殊な電極構造, 封入ガスを採用した超

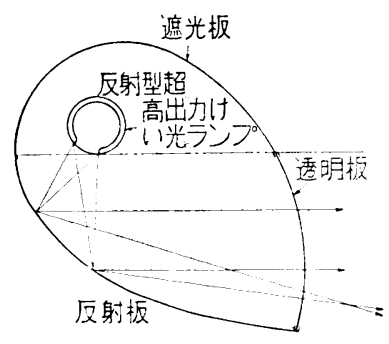
高出力けい光ランプ (FLR-110 EH) に打 いて, 管の内面に $30^{\circ}$ ないし $60^{\circ}$ の開口部を 残して，光反射物質扔 よびけい光体を塗布し た反射型けい光ランプ である。

本ランチ゚では光束の

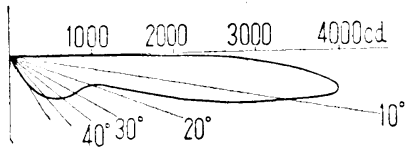
大部分は透明な開口部 分から射出されて, 鋭 い集光性をもってい る.
3. 定格 寸法. 特性は下表の通りである.

\begin{tabular}{|c|c|c|c|c|c|c|c|c|}
\hline 型 式 & 別 & $\begin{array}{l}大 き \vec{z} \\
\text { (W) }\end{array}$ & $\begin{array}{l}\text { 管径 } \\
(\mathrm{mm})\end{array}$ & $\begin{array}{c}\text { 管長 } \\
(\mathrm{mm}) \\
\end{array}$ & $\begin{array}{l}\text { ランブ } \\
\text { 電流 } \\
(\mathrm{A})\end{array}$ & 口金 & $\begin{array}{l}\text { 開口部光束 } \\
\text { 発散度 (rl } \\
\text { x) } 30^{\circ} \text { 開口 }\end{array}$ & $\begin{array}{l}\text { 平均寿 } \\
\text { 命侍間) } \\
\text { ( }\end{array}$ \\
\hline$A-w$ & 巴 & 11 & 38 & 1,150 & 1.5 & $\begin{array}{l}\text { R.D. } \\
\text { C. }\end{array}$ & 237,000 & \\
\hline
\end{tabular}

4. 用途本ランプは特に設計された器具 (AFR 灯具) と組合わせて道路, 橋梁, 駐車場, 滑走路等の照 明を行なうものである。

5. 製作所 新日本電匃株式会社 